\title{
Metaxinic Effect of Some Male Date Palms on "Zaghloul" and "Samany" Fruits
}

\author{
Safaa M. El-Nawam
}

Horticulture Research Institute, Egypt.

Received on: 5/2/2018

Accepted for publication on: 13/2/2018

\begin{abstract}
This study carried out during 2015 and 2016 to detect the influence of pollen obtained from different male date palms on some fruit quality for "Samany" and "Zaghloul" date cultivars grown in Edko, El-Behera Governorate, Egypt. This study aimed to evaluate the influence of various pollinizers when pollinated the female "Samany" and "Zaghloul" date cvs. to examine metaxinic effect on fruit quality. The pollen from each pollinizer given code numbers: (I, II, III and IV) were used for pollinating female "Samany" and "Zaghloul" date cultivars by placing sex male strands within each female spathe. At harvest time (Khalal Stage) a collective sample of 30 fruits was taken from each replicate to determine fruit dimensions, fruit weight, flesh and seed weight. Also, chemical properties was determined such as total soluble solids (TSS), acidity percentage, TSS/acidity, vitamin C, total sugar percentage and soluble tannins content. The obtained results recorded that fruit quality of "Samany" and "Zaghloul" dates was influenced to different pollinizers. In addition, there were variation in fruit quality as a resulted by different pollinizer in both cultivars. Some males produced higher fruit quality when pollinated the female with these males as compared to others. The results showed that the highest values in most testing parameters of "Zaghloul" and "Samany" for fruit quality were obtained when pollinated with pollinizer No.II. Thus, we are recommended to propagate the studied male No. II with any suitable mean.
\end{abstract}

Keyword: Metaxenia, Date palm, Male palm, Pollination, Pollinizers, Samany cultivar, Zaghlol cultivar, Fruit quality.

\section{Introduction}

Egypt is considered the leader of the world and Arab countries in producing date palms (Phoenix dactylifera L.). Where the area was 104851 feddans and the female palm growing in Egypt were 12827235 which produce 1465030 tons according to statistics of Ministry of agriculture (2014). In spite of the rank of Egypt worldwide in the production of dates as the second country following Iran (Ziad and Dewet, 1999). In addition, there is need to increase the production to meet the demands of rapidily expanding population and export. Date palm is one of the most important fruit crops healthy components (Farag, 2016) since the fruit is loaded with sugars, nutrients and antioxdants. Date palm is a dioeciously plant in wich artificial pollination is essential for economical crop and it is necessary for successful fruit set and fruiting. Many investigators proved that the different males not only influence the size and shape of seed (Xinia) but also has direct effect on fruit set, yield and fruit physical and chemical characteristics (Metaxinia). Pollen source play important role in fruit set, present studies were con- 
ducted with the aim to explore best pollinizer to preduce the best fruit quality when pollinated the female of "Zaghloul" and "Samany" cultivars during seasons 2015 and 2016. According to evaluate the effect of using different pollinizers on physical and chemical properties of "Samany" and "Zghloul" dates where the palms grow in sandy soil at private orchard located in Edko region, El-Behera Governorate, Egypt.

\section{Materials and Methods}

The present investigation was carried out during two successive seasons 2015 and 2016 on "Zaghloul" and "Samany" date palms (Phoenix dactylifera, L.). The selected date palms were twelve- years old, grown in a private orchard located at Edco region, El- Behera governorate, Egypt. The palms were grown in sandy soil, planted at $(10 \times 10)$ meters apart and received common cultural practices. Male and female date palms were grown in the same orchard which had been subjected to the same agriculture practices. For this experiment, four male palms were used to pollinate the female "Zaghloul" and "Samany" date palms. Three palms from each female cultivar were selected for this experiment (replicate $=3$ ). The pollen from four male date palms given code number I, II, III and IV, were used for pollinating "Samany" and "Zaghloul" date palms during the two successive seasons 2015 and 2016. The selected female palms were subjected to the following pollination:

1- Pollinizer No. I.

2- Pollinizer No. II.

3- Pollinizer No. III.

4- Pollinizer No. IV.
The same pollinizer source was used to pollinate the same experiments female palm during both seasons. On each female palm, four spaths were lablled and hand pollinated by placing sex male strands within each female spath from the different pollinizers under this study. At harvest time, (Khalal stage) in 1 and 15 October for "Samany" and "Zagloul" date palms cv., respectively, sample of thirty fruit was taken randomly for each replicate to determine physical and chemical Characteristics as follows:

Physical characteristics included:

- Fruit length and fruit width (cm).

- Fruit weight - seed weight flesh weight (gram)

- Flesh weight to seed weight ratio.

- Flesh thickness. (mm)

\section{Chemical characteristics:}

Chemical characteristics were determined of fresh fruit samples included:-

- Total soluble solids (TSS\%):

Measured in fruit juice using pocket refractometer.

- The percentage of acidity (\%): titratable acidity using $0.1 \mathrm{~N} \mathrm{NaOH}$ were determind according to Egan et al. (1981)

- Total soluble solids to acidity ratio were calculated:

- The vitamin $\mathrm{C}$ content ( $\mathrm{mg} / 100 \mathrm{~m}$ juice) It was determined as (mg/100m Juice) according to Egan et al. (1981).

- The percentage of total sugars: (\%): It was measured according to the method described by Malik and Singh (1980). 
- The percentage of soluble tannins (\%): It was determined by using the method described by Malik and Singh (1980).

The experiment was established as split-plot arrangement in RCBD and the data were analyzed using L.S.D at 0.05 level according to Snedecor and Cochran (1994).

\section{Results}

\section{I- Physical characteristics:}

\section{1-Fruit length:}

The data in Table 1 referred to that there are no significant differences among all applied different pollinizers on fruit length $(\mathrm{cm})$ either in
"Zaghloul" or "Samany" cvs. in both seasons, with the exception of pollinizer No.II which resulted in a significant values of date fruit length in the second season. Moreover the presented data in Table 1, regardless the treatments factor, proclaimed that "Zaghloul "dates had higher significant values of fruit length than "Samany" ones in both seasons. With regard to the interaction between male types and cultivars, it could be noticed that all male types achieved higher fruit length of "Zaghloul" in comparison with "Samany" dates in a consistent manner in both seasons.

Table 1. Influence of different pollinizers on fruit length $(\mathrm{cm})$ for "Samany" and "Zaghloul" date palm cultivars during 2015 and 2016 seasons.

\begin{tabular}{|c|c|c|c|c|c|c|}
\hline \multirow{2}{*}{ Charactractise } & \multicolumn{7}{|c|}{ Fruit length.(cm) } \\
\cline { 2 - 7 } Treatment & Samany & Zaghlol & Mean & Samany & Zaghlol & Mean \\
\cline { 2 - 7 } & $5.14 \mathrm{~b}$ & $6.10 \mathrm{a}$ & $\mathbf{5 . 6 2 a}$ & $5.32 \mathrm{~b}$ & $6.22 \mathrm{a}$ & $\mathbf{5 . 7 8 b}$ \\
\hline Pollinizer I & $5.33 \mathrm{ab}$ & $6.30 \mathrm{a}$ & $\mathbf{5 . 8 1 a}$ & $5.63 \mathrm{~b}$ & $6.70 \mathrm{a}$ & $\mathbf{6 . 1 6 a}$ \\
\hline Pollinizer II & $5.31 \mathrm{ab}$ & $6.14 \mathrm{a}$ & $\mathbf{5 . 7 2 a}$ & $5.69 \mathrm{~b}$ & $6.47 \mathrm{a}$ & $\mathbf{6 . 0 8 a b}$ \\
\hline Pollinizer III & $5.23 \mathrm{~b}$ & $6.01 \mathrm{a}$ & $\mathbf{5 . 6 2 a}$ & $5.63 \mathrm{~b}$ & $6.63 \mathrm{a}$ & $\mathbf{6 . 1 3 a b}$ \\
\hline Pollinizer IV & $\mathbf{5 . 2 5 b}$ & $\mathbf{6 . 1 3 a}$ & & $\mathbf{5 . 5 7 b}$ & $\mathbf{6 . 5 1 a}$ & \\
\hline Mean & LSD 0.5 treatments & 0.248 & LSD 0.5 treatments & 0.369 & \\
\hline & LSD 0.5 cultivars & 0.231 & LSD 0.5 cultivars & 0.704 & \\
& LSD 0.5 interaction & 0.395 & LSD 0.5 interaction & 0.556 & \\
\end{tabular}

\section{2- Fruit diameter:}

The data listed in Table 2 represented the effect of different pollinizers on fruit diameter $(\mathrm{cm})$ of "Zaghloul" and "Samany" date cvs. The average of fruit diameter values was significantly higher in "Samany" fruits than "Zaghloul" fruits in both seasons, with the exception of pollinizer N.III in the second season which resulted in a significant value of date fruit diameter while there were no significant differences between different pollinizers in both seasons. Moreover, the interaction between the different pollinizers and the cultivars had significant increase of fruit diameter in "Samany" dates compared with "Zaghloul" dates in both seasons. On the other hand, no significant values noticed between the different pollinizers with regard to the interaction except to the male No. I in the "Samany" fruits in the second season, which had a lowest significant values of fruit diameter compared with other pollinzers. 
Table 2. Influence of different pollinizers on fruit diameter (cm) for "Samany" and "Zaghloul" date palm cultivars during 2015 and 2016 seasons.

\begin{tabular}{|c|c|c|c|c|c|c|}
\hline \multirow{3}{*}{ Charactractise } & \multicolumn{6}{|c|}{ Fruit diameter.(cm) } \\
\hline & \multicolumn{3}{|c|}{2015} & \multicolumn{3}{|c|}{2016} \\
\hline & Samany & Zaghlol & Mean & Samany & Zaghlol & Mean \\
\hline Pollinizer I & $3.13 b$ & $2.77 \mathrm{c}$ & $2.95 a$ & $3.35 \mathrm{~b}$ & $2.88 \mathrm{c}$ & 3.11b \\
\hline Pollinizer II & $3.24 \mathrm{ab}$ & $2.74 \mathrm{c}$ & $2.99 a$ & $3.48 \mathrm{ab}$ & $2.87 \mathrm{c}$ & $3.17 \mathbf{a b}$ \\
\hline Pollinizer III & $3.19 \mathrm{ab}$ & $2.68 \mathrm{c}$ & $2.94 a$ & $3.62 \mathrm{a}$ & $2.90 \mathrm{c}$ & $3.26 \mathrm{a}$ \\
\hline Pollinizer IV & $3.26 \mathrm{a}$ & $2.65 \mathrm{c}$ & 2.95a & $3.54 \mathrm{a}$ & $2.81 \mathrm{c}$ & $3.17 \mathbf{a b}$ \\
\hline \multirow[t]{3}{*}{ Mean } & $3.20 \mathrm{a}$ & $2.71 \mathrm{c}$ & & 3.50a & $2.86 \mathrm{~b}$ & \\
\hline & $\begin{array}{l}\text { LSD } 0.5 \text { treatment } \\
\text { LSD } 0.5 \text { cultivars }\end{array}$ & $\begin{array}{l}0.104 \\
0.011\end{array}$ & \multirow{2}{*}{\multicolumn{2}{|c|}{$\begin{array}{l}\text { LSD } 0.5 \text { treatments } \\
\text { LSD } 0.5 \text { cultivars } \\
\text { LSD } 0.5 \text { interaction }\end{array}$}} & \multirow{2}{*}{\multicolumn{2}{|c|}{$\begin{array}{l}122 \\
247 \\
\end{array}$}} \\
\hline & LSD 0.5 interactio & 0.113 & & .5 interaction & & \\
\hline
\end{tabular}

\section{3- Fruit weigh:}

The results in Table 3 showed that the effect of different pollinizers type observed that there were significant reduction in fruit weight $(\mathrm{g})$ when it were pollinated with pollinizer No. I as compared with other pollinizers, while the average of fruit weight values was no significant between both cultivars in both seasons.
In addition, the interaction between male types and cultivars, the data showed that the pollination with male No.II caused a significant increase in fruit weight in both cultivars in the first season, while this effect showed in "Samany" only in the second season. pollinated with the female dates with male No. III.

Table 3. Influence of different pollinizers on fruit weight (g) for "Samany" and "Zaghloul" date palm cultivars during 2015 and 2016 seasons.

\begin{tabular}{|c|c|c|c|c|c|c|}
\hline \multirow{3}{*}{ Treatment } & \multicolumn{6}{|c|}{ Fruit weight.(g) } \\
\hline & \multicolumn{3}{|c|}{2015} & \multicolumn{3}{|c|}{2016} \\
\hline & Samany & Zaghlol & Mean & Samany & Zaghlol & Mean \\
\hline Pollinizer I & $21.56 \mathrm{e}$ & $23.12 \mathrm{~d}$ & $22.34 c$ & $24.64 c$ & $24.27 \mathrm{c}$ & $24.45 b$ \\
\hline Pollinizer II & $25.24 \mathrm{a}$ & $25.68 \mathrm{a}$ & $25.46 a$ & $30.02 \mathrm{a}$ & $27.25 \mathrm{abc}$ & 28.63a \\
\hline Pollinizer III & $24.44 b$ & $23.24 \mathrm{c}$ & 23.84b & $29.87 \mathrm{ab}$ & $26.86 b c$ & $28.36 a$ \\
\hline Pollinizer IV & $22.45 \mathrm{~d}$ & $23.04 \mathrm{~cd}$ & $22.74 b c$ & $28.73 \mathrm{ab}$ & $28.82 \mathrm{ab}$ & $28.77 a$ \\
\hline \multirow[t]{2}{*}{ Mean } & $23.42 \mathrm{a}$ & $23.77 a$ & & 28.31a & $26.80 a$ & \\
\hline & $\begin{array}{l}\text { LSD } 0.5 \text { treatment } \\
\text { LSD } 0.5 \text { cultivars } \\
\text { LSD } 0.5 \text { interactio }\end{array}$ & $\begin{array}{l}.419 \\
2.100 \\
0.631\end{array}$ & \multicolumn{2}{|c|}{$\begin{array}{l}\text { LSD } 0.5 \text { cultivars } \\
\text { LSD } 0.5 \text { interaction }\end{array}$} & $\begin{array}{l}62 \\
49 \\
139\end{array}$ & \\
\hline
\end{tabular}

\section{4- Flesh weight:}

The data in Table 4 reported the effect of different male types on flesh weight $(\mathrm{g})$, it could be notice that the female dates had the highest significant values of flesh weight when pollinated with pollinizer No.II in both cultivars in the first season, while in the second season, the lowest significant values were obtained with pollinizer No.I than other pollinizers. On the other hand, the effect of the cultivar on flesh weight was non- significant in a consistent manner for both seasons. With regard to the interaction between the male types and cultivars, it could be observed that the highest significant value of flesh weight was obtained with pollinizer No.II than the other applied pollinizers in the first season. On the other hand the results recorded in the second season showed that there were lowest significant flesh weight in "Samany" and "Zaghloul" when pollenated with pollinizer No.I. 
Table 4. Influence of different pollinizers on flesh weight (g) for "Samany" and "Zaghloul" date palm cultivars during 2015 and 2016 seasons

\begin{tabular}{|c|c|c|c|c|c|c|}
\hline \multirow{3}{*}{$\begin{array}{l}\text { Charactractise } \\
\text { Treatment }\end{array}$} & \multicolumn{6}{|c|}{ Flesh weight.(g) } \\
\hline & \multicolumn{3}{|c|}{2015} & \multicolumn{3}{|c|}{2016} \\
\hline & Samany & Zaghlol & Mean & Samany & Zaghlol & Mean \\
\hline Pollinizer I & $19.14 \mathrm{e}$ & $21.16 \mathrm{bcd}$ & $20.15 b$ & $23.29 b$ & $24.58 \mathrm{ab}$ & 23.93a \\
\hline Pollinizer II & $22.36 \mathrm{ab}$ & $23.69 a$ & $23.02 a$ & $27.04 a$ & $25.25 \mathrm{ab}$ & $26.14 a$ \\
\hline Pollinizer III & $21.85 \mathrm{abc}$ & $20.15 \mathrm{cde}$ & $21.00 b$ & $26.88 \mathrm{a}$ & $24.78 \mathrm{ab}$ & $25.83 a$ \\
\hline Pollinizer IV & $19.61 \mathrm{de}$ & $20.85 \mathrm{bcde}$ & $20.23 b$ & $25.89 \mathrm{ab}$ & $26.59 a$ & 26.24a \\
\hline Mean & $20.74 a$ & $21.46 a$ & & $25.77 \mathbf{a}$ & $25.30 a$ & \\
\hline & $\begin{array}{l}\text { LSD } 0.5 \text { treatm } \\
\text { LSD } 0.5 \text { cultiva } \\
\text { LSD } 0.5 \text { interac }\end{array}$ & $\begin{array}{ll}\text { ths } & 1.147 \\
& 2.503 \\
\text { on } & 1.937\end{array}$ & & $\begin{array}{l}\text { LSD } 0.5 \text { treatme } \\
\text { LSD } 0.5 \text { cultivar } \\
\text { LSD } 0.5 \text { interacti }\end{array}$ & $\begin{array}{l}2.753 \\
1.023 \\
3.111\end{array}$ & \\
\hline
\end{tabular}

\section{5- Seed weight:}

The effect of male type, (Table 5) on seed weight $(\mathrm{g})$ recorded nonsignificant differences between them at both season. On the other hand, the highest significant values of seed weight were obtained from "Samany" dates as compared with "Zaghloul" ones.
With regard to the interaction between the cultivars and male types, it could be noticed that there were higher significant values in seed weight of the "Samany" dates when comparing those of "Zaghloul" ones in both seasons.

Table 5. Influence of different pollinizers on seed weight (g) for "Samany" and "Zaghloul" date palm cultivars during 2015 and 2016 seasons.

\begin{tabular}{|c|c|c|c|c|c|c|}
\hline \multirow{3}{*}{$\begin{array}{l}\text { Charactractise } \\
\text { Treatment }\end{array}$} & \multicolumn{6}{|c|}{ Seed weight.(g) } \\
\hline & \multicolumn{3}{|c|}{2015} & \multicolumn{3}{|c|}{2016} \\
\hline & Samany & Zaghlol & Mean & Samany & Zaghlol & Mean \\
\hline Pollinizer I & $2 . .80 a$ & $2.12 \mathrm{c}$ & $2.46 a$ & $2.66 \mathrm{a}$ & $2.15 b$ & $2.40 \mathrm{a}$ \\
\hline Pollinizer II & $2.70 \mathrm{ab}$ & $1.99 \mathrm{c}$ & $2.34 a$ & $2.43 a b$ & $1.98 \mathrm{~b}$ & $2.22 \mathrm{a}$ \\
\hline Pollinizer III & $2.71 \mathrm{ab}$ & $2.23 b c$ & $2.47 \mathrm{a}$ & $2.48 \mathrm{ab}$ & $2.08 \mathrm{~b}$ & $2.28 \mathrm{a}$ \\
\hline Pollinizer IV & $2.84 \mathrm{a}$ & $2.01 \mathrm{c}$ & $2.42 a$ & $2.86 \mathrm{a}$ & $2.01 \mathrm{~b}$ & $2.43 a$ \\
\hline \multirow[t]{3}{*}{ Mean } & $2.76 a$ & $2.08 b$ & & $2.60 \mathrm{a}$ & $2.06 b$ & \\
\hline & $\begin{array}{l}\text { LSD } 0.5 \text { treatmen } \\
\text { LSD } 0.5 \text { cultivars }\end{array}$ & $\begin{array}{l}0.291 \\
0.373\end{array}$ & & $\begin{array}{l}\text { LSD } 0.5 \text { treatment } \\
\text { LSD } 0.5 \text { cultivars }\end{array}$ & $\begin{array}{l}0.303 \\
0.158\end{array}$ & \\
\hline & LSD 0.5 interactic & 0.494 & & LSD 0.5 interactiol & 0.494 & \\
\hline
\end{tabular}

\section{6- Flesh to seed ratio:}

The presented data in Table 6 showed that fruits resulted from male No.II had the highest flesh to seed weight ratio as compared with ones resulted from other applied males in the first season. Moreover, the data stated that the ratio of flesh to seed weight was significantly higher in "Zaghloul'.' dates as compared with
"Samany" ones. In addition, the effect of interaction between cultivars and applied male types in Table 6 showed that the highest values of flesh to seed weight ratio were obtained of dates pollenated with males No. II and IV in both seasons of "Zaghloul" date cvs., while those obtained with males No.II and II in both seasons of "Samany" date cvs. 
Table 6. Influence of different pollinizers on flesh weight to seed weight ratio for "Samany" and "Zaghloul" date palm cultivars during 2015 and 2016 seasons.

\begin{tabular}{|c|c|c|c|c|c|c|}
\hline \multirow{3}{*}{ Treatment } & \multicolumn{6}{|c|}{ Flesh weight to seed ratio weight } \\
\hline & \multicolumn{3}{|c|}{2015} & \multicolumn{3}{|c|}{2016} \\
\hline & Samany & Zaghlol & Mean & Samany & Zaghlol & Mean \\
\hline Pollinizer I & $6.83 \mathrm{e}$ & $9.98 \mathrm{bc}$ & $8.41 b$ & $8.86 \mathrm{~d}$ & $11.67 \mathrm{bc}$ & $10.27 \mathbf{a}$ \\
\hline Pollinizer II & $8.39 \mathrm{cde}$ & 11.91a & $10.15 a$ & $11.44 b c$ & $12.71 \mathrm{~b}$ & $10.07 a$ \\
\hline Pollinizer III & $8.07 \mathrm{de}$ & $9.22 \mathrm{bcd}$ & $8.64 b$ & $10.86 \mathrm{c}$ & $12.10 \mathrm{bc}$ & $11.48 \mathrm{a}$ \\
\hline Pollinizer IV & $6.90 \mathrm{e}$ & $10.43 \mathrm{ab}$ & $8.66 \mathrm{~b}$ & $9.07 \mathrm{~d}$ & $14.69 \mathrm{a}$ & 11.88a \\
\hline Mean & $7.55 b$ & 10.38a & & 10.00b & 12.79a & \\
\hline & $\begin{array}{l}\text { LSD } 0.5 \text { treatments } \\
\text { LSD } 0.5 \text { cultivars }\end{array}$ & $\begin{array}{l}0.713 \\
2.153\end{array}$ & & $\begin{array}{l}\text { LSD } 0.5 \text { treatments } \\
\text { LSD } 0.5 \text { cultivars }\end{array}$ & $\begin{array}{l}3.127 \\
2.231\end{array}$ & \\
\hline
\end{tabular}

\section{7-Flesh thickness:}

Data introduced in Table 7 showed that the effect of different male types on fruit flesh thickness resulted higher significant values of dates obtained when pollenated with both males No. I and No.II in both seasons. On the other hand, there were significant values of date flesh thickness of "Samany" dates than that of "Zaghloul" ones in a consistent manner to both seasons. The presented data in Table 7 also showed the interaction between male types and cultivars, where all used male types achieved the highest significant values of fruit thickness in "Samany" dates, when comparing with these male types in "Zagnloul" ones and the results were similar in the both seasons.

Table 7. Influence of different pollinizers on flesh thinkness (mm) for "Samany" and "Zaghloul" date palm cultivars during 2015 and 2016 seasons.

\begin{tabular}{|c|c|c|c|c|c|c|}
\hline \multirow{3}{*}{ Treatment } & \multicolumn{6}{|c|}{ Flesh thinkness. (mm) } \\
\hline & \multicolumn{3}{|c|}{2015} & \multicolumn{3}{|c|}{2016} \\
\hline & Samany & Zaghlol & Mean & Samany & Zaghlol & Mean \\
\hline Pollinizer I & $5.70 \mathrm{a}$ & $4.16 \mathrm{~cd}$ & 4.93b & $6.93 a$ & $5.23 \mathrm{~b}$ & $6.08 a$ \\
\hline Pollinizer II & $6.06 \mathrm{ab}$ & $4.40 \mathrm{~cd}$ & $5.23 \mathrm{ab}$ & $7.06 \mathrm{a}$ & $5.26 \mathrm{~b}$ & $6.16 a$ \\
\hline Pollinizer III & $6.63 a$ & $4.706 \mathrm{c}$ & $5.70 \mathrm{a}$ & $7.06 \mathrm{a}$ & $4.93 b$ & $6.00 \mathrm{~b}$ \\
\hline Pollinizer IV & $6.66 \mathrm{a}$ & $3.90 \mathrm{~d}$ & 5.28ab & $7.06 \mathrm{a}$ & $4.26 \mathrm{c}$ & $5.66 \mathrm{~b}$ \\
\hline \multirow[t]{2}{*}{ Mean } & $6.26 a$ & $4.30 \mathrm{~b}$ & & $7.03 a$ & $4.92 b$ & \\
\hline & $\begin{array}{l}\text { D } 0.5 \text { treatments } \\
\text { D } 0.5 \text { cultivars }\end{array}$ & $\begin{array}{l}0.380 \\
0.280\end{array}$ & & $\begin{array}{l}0.5 \text { treatments } \\
0.5 \text { cultivars }\end{array}$ & $\begin{array}{l}0.733 \\
0.347\end{array}$ & \\
\hline
\end{tabular}

\section{II- Chemicals characteristics}

8-Total soluble solids (\%):

The data listed in Table 8 represented the effect of male types on the percentages of total soluble solids $(\mathrm{TSS} \%)$, where there were significant higher percentages of TSS in fruit juice using pollinizer male No.I, No.II and No.III in both seasons. On the other hand, there was no significant difference recorded between "Samany" and "Zaghloul" dates in both seasons, with exception in "Samany" of the first season which were significant lower values of the percentage of total soluble solids. The interaction between applied different pollinizer and cultivars, the results 
recorded that the percentage of TSS was higher values in both season obtained when pollenated with pollinizer No.II and No. III in "Samany" and "Zaghloul" dates as compared with other pollinizer, except, in the "Zaghloul" dates, the date recorded the highest values of TSS obtained also when pollinated with male No. IV.

Table 8. Influence of different pollinizers on Total soluble Solids (TSS) in fruit juice of "Samany" and "Zaghloul" date palm cultivars during 2015 and 2016 seasons.

\begin{tabular}{|c|c|c|c|c|c|c|}
\hline \multirow{3}{*}{ Charactractise } & \multicolumn{6}{|c|}{ TSS.(\%) } \\
\hline & \multicolumn{3}{|c|}{2015} & \multicolumn{3}{|c|}{2016} \\
\hline & Samany & Zaghlol & Mean & Samany & Zaghlol & Mean \\
\hline Pollinizer I & $24.16 \mathrm{~cd}$ & $25.66 a b c$ & 24.88a & $26.53 \mathrm{ab}$ & $25.60 \mathrm{~b}$ & 26.06a \\
\hline Pollinizer II & $24.6 \mathrm{bcd}$ & $26.06 \mathrm{abc}$ & 25.33a & $26.26 \mathrm{ab}$ & $26.26 \mathrm{ab}$ & $26.26 a$ \\
\hline Pollinizer III & $24.20 \mathrm{bcd}$ & $26.20 \mathrm{ab}$ & $25.20 \mathrm{a}$ & $27.86 \mathrm{a}$ & $26.20 \mathrm{ab}$ & $27.03 a$ \\
\hline Pollinizer IV & $22.93 \mathrm{~d}$ & $27.53 \mathrm{a}$ & 25.23a & $25.16 b$ & $27.53 a$ & $26.35 a$ \\
\hline \multirow[t]{3}{*}{ Mean } & $23.97 b$ & 26.35a & & 26.45a & 26.40a & \\
\hline & $\begin{array}{l}\text { LSD } 0.5 \text { treatment } \\
\text { LSD } 0.5 \text { cultivars }\end{array}$ & $\begin{array}{l}1.489 \\
0.999\end{array}$ & & $\begin{array}{l}\text { LSD } 0.5 \text { treatments } \\
\text { LSD } 0.5 \text { cultivars }\end{array}$ & $\begin{array}{l}1.504 \\
1.258\end{array}$ & \\
\hline & LSD 0.5 interactio & 2.012 & & LSD 0.5 interaction & 1.864 & \\
\hline
\end{tabular}

\section{9-Fruit acidity (\%):}

The data in Table 9 reported that the percentage of acidity significantly lower in juice "Samany" fruits when pollinated with male No.II and No.IV in both seasons. From the presented data in Table 9, it could be also observed that fruit acidity was significantly higher in "Samany" dates as compared with "Zaghloul" ones in a consistent manner. Moreover, the interaction between applied males and cultivars (Table 9) showed that the percentage of acidity in both cultivars fruits was significantly lower, when pollinated with male No.II and No.IV in both seasons.

Table 9. Influence of different pollinizers on fruit acidity $(\%)$ in fruit juice of "Samany" and "Zaghloul" date palm cultivars during 2015 and 2016 seasons.

\begin{tabular}{|c|c|c|c|c|c|c|}
\hline \multirow{2}{*}{ Charactractise } & \multicolumn{7}{|c|}{ Fruit acidity.(\%) } \\
\cline { 2 - 7 } Treatment & \multicolumn{7}{|c|}{$\mathbf{2 0 1 5}$} & \multicolumn{3}{|c|}{$\mathbf{2 0 1 6}$} \\
\cline { 2 - 7 } & Samany & Zaghlol & Mean & Samany & Zaghlol & Mean \\
\hline Pollinizer I & $1.41 \mathrm{a}$ & $0.76 \mathrm{~d}$ & $\mathbf{1 . 0 8 a}$ & $1.43 \mathrm{~b}$ & $0.61 \mathrm{e}$ & $\mathbf{1 . 0 2 a}$ \\
\hline Pollinizer II & $1.07 \mathrm{c}$ & $0.50 \mathrm{ef}$ & $\mathbf{0 . 7 8 c}$ & $1.04 \mathrm{~d}$ & $0.50 \mathrm{f}$ & $\mathbf{0 . 7 7 b}$ \\
\hline Pollinizer III & $1.31 \mathrm{~b}$ & $0.53 \mathrm{e}$ & $\mathbf{0 . 9 2 b}$ & $1.53 \mathrm{a}$ & $0.57 \mathrm{e}$ & $\mathbf{1 . 0 5 a}$ \\
\hline Pollinizer IV & $1.06 \mathrm{~b}$ & $0.45 \mathrm{f}$ & $\mathbf{0 . 7 5 c}$ & $1.12 \mathrm{c}$ & $0.42 \mathrm{~g}$ & $\mathbf{0 . 7 7 b}$ \\
\hline Mean & $\mathbf{1 . 2 1 a}$ & $\mathbf{0 . 5 6 b}$ & & $\mathbf{1 . 2 8 a}$ & $\mathbf{0 . 5 2 b}$ & \\
\hline & LSD 0.5 treatments & 0.040 & \multicolumn{5}{c}{ LSD 0.5 treatments } & 0.051 & \\
& LSD 0.5 cultivars & 0.077 & LSD cultivars & 0.073 & \\
& LSD 0.5 interaction & 0.062 & & LSD 0.5 interaction & 0.047 & \\
\end{tabular}

\section{0-TSS/ acidity ratio:}

The tabulated data in Table 10 cleared that the highest significant values of TSS to acidity ratio were obtained in dates resulted from the pollination with males No.II and No.IV in both experimental seasons, regardless the cultivar effect. On the other hand, the data indicated that the values of TSS to acidity ratio were 
highest in "Zaghloul" dates as compared with "Samany" in both seasons, Moreover, the effect of interaction between the male types and cultivars were reported that the higher significant values of TSS to acidity ratio

Table 10. Influence of different pollinizers on TSS/acidity ratio in fruit juice of "Samany" and "Zaghloul" date palm cultivars during 2015 and 2016 seasons.

\begin{tabular}{|c|c|c|c|c|c|c|}
\hline \multirow{2}{*}{ Charactractise } & \multicolumn{7}{|c|}{ TSS/acidity ratio } \\
\cline { 2 - 7 } & \multicolumn{7}{|c|}{$\mathbf{2 0 1 5}$} & \multicolumn{3}{|c|}{$\mathbf{2 0 1 6}$} \\
\cline { 2 - 7 } & Samany & Zaghlol & Mean & Samany & Zaghlol & Mean \\
\hline Pollinizer I & $17.15 \mathrm{e}$ & $33.68 \mathrm{c}$ & $\mathbf{2 5 . 4 2 c}$ & $18.56 \mathrm{f}$ & $42.27 \mathrm{~d}$ & $\mathbf{3 0 . 4 1 c}$ \\
\hline Pollinizer II & $23,00 \mathrm{~d}$ & $52.45 \mathrm{~b}$ & $\mathbf{3 7 . 7 3 a b}$ & $25.29 \mathrm{e}$ & $52.76 \mathrm{~b}$ & $\mathbf{3 9 . 0 4 b}$ \\
\hline Pollinizer III & $18.48 \mathrm{de}$ & $49.47 \mathrm{bc}$ & $\mathbf{3 3 . 9 7 b}$ & $18.21 \mathrm{f}$ & $46.11 \mathrm{c}$ & $\mathbf{3 2 . 1 6 c}$ \\
\hline Pollinizer IV & $21.63 \mathrm{~d}$ & $61.53 \mathrm{a}$ & $\mathbf{4 1 . 5 8 a}$ & $22.48 \mathrm{e}$ & $65.80 \mathrm{a}$ & $\mathbf{4 4 . 1 4 a}$ \\
\hline Mean & $\mathbf{2 0 . 0 6 b}$ & $\mathbf{4 9 . 2 8 a}$ & & $\mathbf{2 1 . 1 3 b}$ & $\mathbf{5 1 . 7 4 a}$ & \\
\hline & LSD 0.5 treatments & 5.392 & & LSD 0.5 treatments & 1.814 \\
\\
& LSD 0.5 cultivars & 3.937 & LSD 0.5 cultivars & 9.942 & \\
& LSD 0.5 interaction & 5.682 & & LSD 0.5 interaction & 3.425 &
\end{tabular}

\section{1-Vitamin C:}

The results of vitamin $\mathrm{C}$ in date fruits were listed in Table II. The data revealed that there were higher values of vitamin $\mathrm{C}$ content of fruit resulted when pollinated with pollinizer No.I and No.III in both seasons. Furthermore, "Samany" dates had higher significant values in vitamin C content as comparing with those in were obtained in "Zaghloul" dates resulted from pollination with males No.II, No.III and No.IV as compared with those in "Samany" ones.

Table 11. Influence of different pollinizers on vitamin $C(\mathrm{mg})$ ascorbic acid/ (100 ml juice) of "Samany" and "Zaghloul" date palm cultivars during 2015 and 2016 seasons.

\begin{tabular}{|c|c|c|c|c|c|c|}
\hline \multirow{3}{*}{ Charactractise } & \multicolumn{6}{|c|}{ vitamin C (mg/100 ml juice) } \\
\hline & \multicolumn{3}{|c|}{2015} & \multicolumn{3}{|c|}{2016} \\
\hline & Samany & Zaghlol & Mean & Samany & Zaghlol & Mean \\
\hline Pollinizer I & $11.16 \mathrm{a}$ & $10.00 \mathrm{abc}$ & $10.58 a$ & $14.33 \mathrm{a}$ & $11.50 \mathrm{bc}$ & $12.91 a$ \\
\hline Pollinizer II & $8.00 \mathrm{~cd}$ & $6.83 \mathrm{~d}$ & $7.41 \mathrm{~b}$ & $9.33 \mathrm{de}$ & $10.16 \mathrm{~cd}$ & $9.75 b$ \\
\hline Pollinizer III & $11.16 \mathrm{a}$ & $10.50 \mathrm{ab}$ & $10.83 a$ & $12.66 \mathrm{~b}$ & $11.33 \mathrm{bc}$ & $12.00 a$ \\
\hline Pollinizer IV & $8.66 \mathrm{bcd}$ & $8.16 \mathrm{~cd}$ & $8.41 b$ & $9.66 \mathrm{~d}$ & $8.16 \mathrm{e}$ & $8.91 b$ \\
\hline Mean & $9.75 a$ & $8.87 b$ & & $11.50 \mathrm{a}$ & $10.29 a$ & \\
\hline & $\begin{array}{l}\text { LSD } 0.5 \mathrm{tr} \\
\text { LSD } 0.5 \mathrm{cl} \\
\text { LSD } 0.5 \mathrm{in}\end{array}$ & $\begin{array}{ll}\text { ents } & 1.209 \\
\text { ris } & 0.310 \\
\text { tion } & 2.186\end{array}$ & & $\begin{array}{l}\text { LSD } 0.5 \text { trea } \\
\text { LSD } 0.5 \text { cul } \\
\text { LSD } 0.5 \text { inte }\end{array}$ & $\begin{array}{l}1.588 \\
1.434 \\
1.393\end{array}$ & \\
\hline
\end{tabular}

\section{2-Total sugar (\%):}

The presented data in Table No. 12 showed the effect of different male types on the percentages of total sugars in dates, regardless the effect
"Zaghloul" dates in the first season. The effect of interaction between different pollinizer and cultivars also listed in. (Table 11). The data showed that the highest values of vitamin $\mathrm{C}$ were obtained when pollenated "Samany" and "Zaghloul" dates with male No.I and No.III as compared with those of the other males.

of cultivars. The results indicated that the significantly highest values of total sugars content were obtained when pollinated "Samany" and "Zaghloul" dates with pollinizer No.II in both seasons. On the other hand, 
the effect of cultivars on total sugar percentages in dates was higher significant "Zaghloul" than that in "Samany" dates in the two successive seasons. With regard to the interaction between used male types and cultivars, the data showed that the pollination with male No.II caused higher increase of the percentages of total sugars either of "Samany" or "Zaghloul" dates as comparing with other applied types. Moreover, the highest values of total sugars were noticed in "Zaghloul" dates after pollinated with either pollinizer No.II or No.III in both seasons.

Table 12. Influence of different pollinizers on Total sugars in fruit juice of "Samany" and "Zaghloul" date palm cultivars during 2015 and 2016 seasons.

\begin{tabular}{|c|c|c|c|c|c|c|}
\hline \multirow{3}{*}{ Charactractise } & \multicolumn{6}{|c|}{ Total sugars (\%) } \\
\hline & \multicolumn{3}{|c|}{2015} & \multicolumn{3}{|c|}{2016} \\
\hline & Samany & Zaghlol & Mean & Samany & Zaghlol & Mean \\
\hline Pollinizer I & $20.73 c$ & $26.76 \mathrm{~b}$ & $23.75 b$ & $25.70 \mathrm{~b}$ & $26.13 b$ & 25.91b \\
\hline Pollinizer II & $24.70 \mathrm{~b}$ & $33.53 \mathrm{a}$ & 29.11a & $29.86 a$ & $31.83 \mathrm{a}$ & 30.85a \\
\hline Pollinizer III & $24.03 b c$ & $32.46 a$ & $28.25 a$ & $23.76 \mathrm{bc}$ & $30.06 \mathrm{a}$ & 26.91b \\
\hline Pollinizer IV & $20.83 c$ & $24.60 \mathrm{~b}$ & $22.71 b$ & $20.46 \mathrm{~d}$ & $22.90 \mathrm{~cd}$ & $21.68 \mathrm{c}$ \\
\hline \multirow[t]{2}{*}{ Mean } & $22.57 b$ & 29.34a & & $24.95 b$ & 27.73a & \\
\hline & $\begin{array}{l}0.5 \text { treatments } \\
0.5 \text { cultivars } \\
0.5 \text { interaction }\end{array}$ & & $\begin{array}{l}\text { LSD } \\
\text { LSD }\end{array}$ & $\begin{array}{ll}\text { atments } & 3.1 \\
\text { tivars } & 2.6 \\
\text { exartion }\end{array}$ & & \\
\hline
\end{tabular}

\section{3-Soluble tannins:}

The effect of varied male types on the percentage of soluble tannins was shown in Table No.13. The data revealed that soluble tannins were significantly lower when pollinated with male No.II, while the highest significant values were noticed when pollinated with the female dates with male No.III in a consistent manner in the two seasons. On the other hand, the data showed that there was no significant difference between both cultivars in their effects on soluble tannins in both seasons. With regard to the interaction between different pollinizers and cultivars it could be noticed tat the lowest significant for total soluble tannins values were obtained when pollenated "Samany" and "Zaghloul" dates with male No.II in both seasons. Also, the lowest value of the percentage of soluble tannins were obtained when pollenated "Samany" dates with male No.IV in both seasons in a consistent manner in the two season.

Table 13. Influence of different pollinizers on Soluble tannins in fruit juice of "Samany" and "Zaghloul" date palm cultivars during 2015 and 2016 seasons.

\begin{tabular}{|c|c|c|c|c|c|c|}
\hline \multirow{3}{*}{ Treatment } & \multicolumn{6}{|c|}{ Soluble tannins (gm/100 ml juice). } \\
\hline & \multicolumn{3}{|c|}{2015} & \multicolumn{3}{|c|}{2016} \\
\hline & Samany & Zaghlol & Mean & Samany & Zaghlol & Mean \\
\hline Pollinizer I & $1.55 \mathrm{ab}$ & $1.69 \mathrm{a}$ & $1.62 a$ & $1.41 b c$ & $1.33 \mathrm{bcd}$ & $1.37 \mathrm{~b}$ \\
\hline Pollinizer II & $1.19 \mathrm{~cd}$ & $1.05 \mathrm{~d}$ & $1.12 \mathrm{c}$ & $1.04 \mathrm{~d}$ & $1.06 \mathrm{~d}$ & $1.05 c$ \\
\hline Pollinizer III & $1.53 \mathrm{ab}$ & $1.53 \mathrm{ab}$ & $1.53 a$ & $1.62 \mathrm{ab}$ & $1.83 \mathrm{a}$ & $1.73 a$ \\
\hline Pollinizer IV & $1.23 \mathrm{~cd}$ & $1.35 \mathrm{bc}$ & $1.29 \mathrm{~b}$ & $1.14 \mathrm{~cd}$ & $1.48 \mathrm{~b}$ & $1.31 \mathrm{~b}$ \\
\hline Mean & $1.38 \mathrm{a}$ & $1.41 \mathrm{a}$ & & 1.30a & 1.43a & \\
\hline & $\begin{array}{l}\text { LSD } 0.5 \text { treatments } \\
\text { LSD } 0.5 \text { cultivars } \\
\text { LSD } 0.5 \text { interaction }\end{array}$ & & & $\begin{array}{l}\text { LSD } 0.5 \text { treatr } \\
\text { LSD } 0.5 \text { culti } \\
\text { LSD } 0.5 \text { inter }\end{array}$ & $\begin{array}{ll}\text { s } & 0.236 \\
& 0.341 \\
0322\end{array}$ & \\
\hline
\end{tabular}




\section{Discussion}

Pollen have direct effect on the physical and chemical properties of fruit (Shafique et al. 2011).

\section{I- Physical properties:}

The obtained results showed that fruit length and fruit width were significant different when pollinated with different males. The obtained results partially agreed with the findings of Omar et al. (2014) who reported that pollen sources significant affect the fruit length. Also, Hamid (2000) and Marzouk et al. (2002) who reported that pollen source have significant effect on fruit width. The results showed that fruit weight were significantly affected by different pollinizer during both seasons, lower weight of fruit was recorded when pollinated with male No. I in both seasons for two cultivars, while higher weight of fruit was produced when pollinated with male No. II in both cultivars in the first season while this effect recorded in "Samany" only in the second season. These results are in line with findings of Omer et al. (2014) who reported that pollen sources had significant effect on fruit weight. Also, similar results were reported by Simozarag et al. (2016). The effect of male type on seed weight were not significant in both seasons, this results are in line with the fact that the pollens have direct effect on the meternal tissue of fruit which is known as Metaxnia (Janick, 1979) it could may due to that males had differed in floral characteristics (Iqbal et al. 2008, 2009) Also, Ismail (2014) reported that germination percentage of pollen varies from male to another. Our results were produced significantly increase in flesh weight values in both cultivars when pollinated with male No. II in both seasons, while the lowest significant values had obtained when pollinated with male No. I compared with other pollinizers. These results are in line with findings of Osman and Soliman (2002), Marzouk et al.(2002) AlObeed and Abd El Rahman (2002) and El-Kosary and Soliman (2003) who reported that different male pollens have significantly effect on fruit weight, size and pulp as well as fruit yield. There were variations between pollen quantity effects on fruit quality and fruit anatomy recorded that the lowest layers dimensions thickness in epiderm cells, stone cells, outer mesocarp cells, tannin cells and inner mesocarp.

\section{II- Chemical properties:}

Fruit total soluble solids were recorded highest values for dates when pollinated with pollinizer No. II and No.III in both seasons as compared with other pollinizers. These results agree the findings of Shafique et al. (2011) who reported that different pollinizer have significant effect on fruit TSS. Also, these results agree with Kalifa et al. (1979) who reported that TSS content differenced according to pollen source.

\section{Acidity:}

The lowest values of acidity content were observed when pollinated with male No. II and No. IV in both seasons, while the highest values of acidity were obtained from "Samany" fruits than those of "Zaghloul" fruits. These results agree with those findings of El-Azzuny et al. (1975) and Mowloud (1990) on "Samany" and "Zaghloul" cultivars.

\section{Total sugars:}


The results showed that the highest values of total sugars of fruits were obtained when pollinated with male No.II and No.III as compared with those of other pollinizer. Also, total sugars of fruit were differed as influence of pollinated with different pollinizer, these results are in line with those of Khalifa et al. (1979), Hegazy et al.(1982) and Nour and Jaaim (1984) who reported that total sugar content of fruits varies according to different pollen grains treatments. Also, these results are agreed with those obtained by El-Azzuny et al. (1975), Baker et al.(1981), ElMakhtoun et al. (1988 and 1995) and Youssef et al. (1999) on different cultivars of date palm.

\section{Tannins:}

The results recorded that the values of soluble tannins content were significant low in fruits when pollinated male No. II in both seasons. While the highest values of tannins were obtained when pollinated with male No. III for "Samany" and "Zaghloul" dates. Similar results were observed by Hussein (1982) and ElMakhtoun et al. (1990 and 1995) on different cultivars of date palm, who reported that pollen type affected of the tannins content in the produced fruits. Pollination encourage boron that increase hormones, these hormones and boron stimulate carbohudrates metabolism. Nijar (1985). These differences between different pollinizers under this study could be due to the variability in their genetic expression.

\section{Conclucsion:}

The obtained results showed that the various pollinizers had different influence on fruit quality of
"Zaghloul" and "Samany" dates under the condition of Edco region, ElBehera Governorate, Egypt. In addition, our results recorded that the best values in most fruit quality parameters of "Zaghloul" and "Samany" dates were obtained when pollinated with pollinizer No.II. It seems that pollen of this pollinizer has the highest compatibility with the female cultivars under this study. Consequently, it could be recommended to propagate the studied male No. II with any suitable vegetative propagation methods.

\section{References}

Al-Obeed, R.S and A.O.Abdul-Rahman. (2002). Compaibility relationships within and between ten date palm cultivars (Phoenix dactylifera L.) I- Fruit set and yield. J. Adv. Agric. Res 7: 809-820.

Bakr, E.I., M.A. Shaheen, M.A.Osman and A.E. Mowlood (1981). Some chemical constituent of Samani and Zaghloul fruits as affected by 2,4-D GA $\mathrm{GA}_{3}$ and/or pollination (part II) Bull. Fac. Agric. Cairo. Univ. Vol. XXXII.

Egan,H.; Kird, R.S. and Sawyer, R. (1981). Pearson's chemical Analysis of foods. Eighth Edition Longman Scientific and Technical Essex $\mathrm{CM}_{20}$ 2TE, England.

El-Azzouny, M.M.; M.T.Kabeel; E.I. Bakr and M. Hy Abdel Rahman (1975). Developmental changes in fruit characters and maturity determination of two date palm varieties. Annals Agric. Sci. Moshtohor, 4:221-234.

El-Kosary, S. and S.S. Soliman. (2003). Samani and Zaghloul date palm cultivars (Phoenix dactylifera L.) productivity as influenced by different pollen source and two hand pollination methods. Assiut J. Agric. Sci. 34(2): 65-97. 
El-Makhtoun, F.B.; H.H.Selim and E.L.Bakr (1988). Effect of pollination and growth regulators spray on chemical characteristics of Samani date fruit. Propagation symposium and palm cultivation in Arab countries, El-Ain, U.A. Imarat, September 5-10.

El-Makhtoun, F.B.; A.M. Abdel-Kader and B.B.Basta Wros. (1990). Effect of leaf/brunch ratio on yield and fruit quality of "Khadrawi" and "Samani" dates. J. Agric. Soc. Mansoura Univ. Egypt. 15(5): 696704.

El-Makhtoun, F.B.; A.M.Abdel-Kader and A.A. Abd El-Al (1995). Effect of different pollination method on yield and fruit quality of Zaghloul date cultivar. Zagazig j. Agric.Res. Egypt. Vol. 22 No.(1):151 - 157.

Farag, K. M. (2016). Date palm, A Wealth of Healthy Food. Encyclopedia of Food and Health (FOHE). Chapter, 00215. Elsever, MRW Production Department at: MRW FOHE@ebevier.com.

Hamid, A.A.N. (2000). Effect of time, rate and patterns of thinning, leaf brunch ratio and male type on Zaghloul date yield and quality. Arab. J. Agric. Sci. 8(1): 305-317.

Hegazy, M.K.; S.H.Elghay and F.B.AlMakhtoun (1982). Effect of different pollen types on fruit chemical properties of some date varieties. Proceedings of the fruit symposium on the date palm. King Fusial Univ. in Soudi.

Hussein, F. (1982). Pollination of date palm and its effect on production and quality of fruits. Proc. $1^{\text {st }}$ Symp. on date palm in Soudia Arabia (1): 14-24.

Iqbal, M., G. Jalatudins and M. Munir. (2008). Effect of male pollinizers on fruit characters and yield index of date palm (Phoenix dactylifera L.) cvs Zahidi and Dhakki. PARC.
Islamabad. Pak. J. Agric. Res. 21 (1-4): $79-85$.

Iqbal, M., Jalaludin, M.Munir and Mohibullah. (2009). Floral characters of male palm used in pollination of Cv Dhakki for fruit set and yield. PARC. Islamabad Pak. J. Agric. Res. 22 (1-2): 36-41.

Ismail, O.M. (2014). In vitro germination of date palm pollen grains affected by different sugars types. Res. J.Pharma. 5(1):880-886.

Janick, J. (1979). Horticultural Science $3^{\text {rd }}$ (eds. W.H.Freeman and company San Francisco) PP. 604.

Khalifa, A.S., Z Hamdy, S. Azoouz, H. Maary and N. Yosef. (1979). Effect of source of pollen on the physical and chemical quality of "Amhat" date variety. Hort. Res. Inst. Agric. Res. Center, Ministry of Agric. Egypt.

Malik, C.P. and M.B singh (1980). Plant enzymology and histonzymology. A. Text Manual, Kalyani publishers, New Delhi.

Mawlood, E.A. (1990). Physiological studies on fruit development of Samani and Zaghloul date palm cultivars. Ph.D. Thesis. Hort. Dept. Agric. Fac. Cairo Univ.

Marzouk, H.M., A.M. El-Salhy and R.A. Hassan (2002). Effect of male type and receptivity of pistillate flowers and fruit set, yield and some physical fruit properties of Zaghloul and Samany date palm cultivars. Proc. of Minia $1^{\text {st }}$ Conference for Agriculture and Environ. Sci., Minia, Egypt. March. 2528: 1013-1023.

Ministry of agriculture (2014). Statistics of fruit cultivations agriculture, A.R.E.

Nijjar, G.S. (1985). Nutrition of fruit trees in fertilizers and manures (Eds-Kumar, U. R), Kilyani press, New Delhi, India, 206-234 pp. 
Nour, G.M. and A.M. Jaaim (1984). Effect of different date pollen grains on fruit characteristics of "Khadrawi" and "Maktum" date cultivars. Agric. Res. Review vol.62, No.3 A: $267-275$.

Omer, A., R. Al-Obeed and M. Ahmed. (2014). Metaxinic effects of related to male palm (Phoenix dactylifera L.) and (Phoenix cariances) yield and quality of date fruit. J. Food Agric. Environ. 12 (2): $523-525$.

Osman, S.M. and S.S. Soliman. (2002). Effect of different pollen grains and pollination time on fruit quality of Zaghloul date cultivar under north Sinai conditions. Assiut J. Agric. Sci. 33 (5): 47 - 58.

Shafique, M., A.S. Khan, A.U. Malik, M.S. Shahid, I.A. Rajwana, B.A. Saleem, M. Amin and A. Ahmed (2011). Influence of pollen source and pollination frequency on fruit drop, yield and quality of Date palm $\mathrm{Cv}$ Dhakki. Pak. J. Bot. 43(2): 831-839.
Snedecor, G.W. and W.G. Cochran. (1994). Statistical Methods. $6^{\text {th }}$ edn Oxford and IBN.

Swain, T. and W.E. Hillis (1959). The phenolic constituents of prunus domestica L.L. The quantitative analysis of phenolic constituents. J. Sci. Food Agric., 10:63 - 68.

Simozrag, A.C. Adel, A. Djerouni and E.B. Mouhamed (2016). Phenotypic diversity of Date Palm cultivars (Phoenix dactylifera L.) deArgelia Gayana. Bot. 73(4):4253.

Youssef, M.K.; M. N. El-Rify; M. A., Geddawy and B. R. Ramadan (1999). Nutrient elements and vitamins content of some new valley dates and certain date products. The international conference on Date palm 9-11 Environmental studies, Egypt.

Ziad, A. and DeWet,P.F (1999). Origin, geographical distribution and nutritional values of date palm. In: Date palm cultivation Eds. Zind. A, and Arias-Jimenez, E.J. Vol. 156 Pp. 26-44 FAO plant production and protection, Rome, Italy. 
التأثير الميتازيني لبعض ذكور النخيل على ثمار البلح الزغلول و السماني

صفاء محمد النوام

معهد بحوث البساتين - مصر

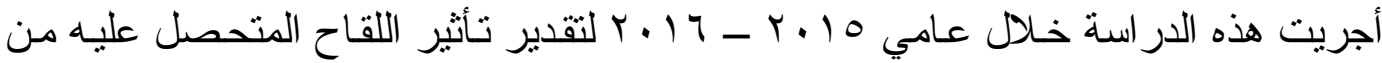

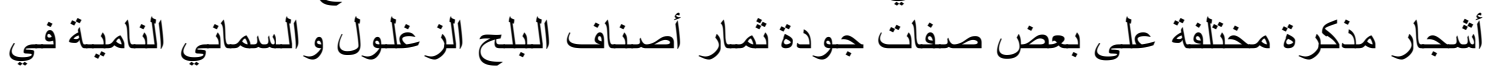

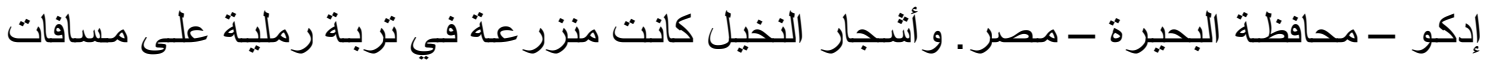

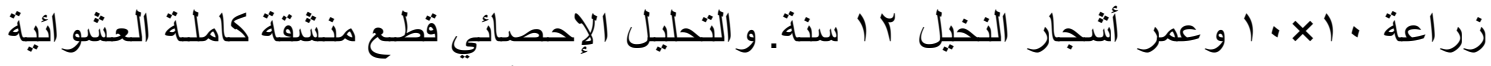

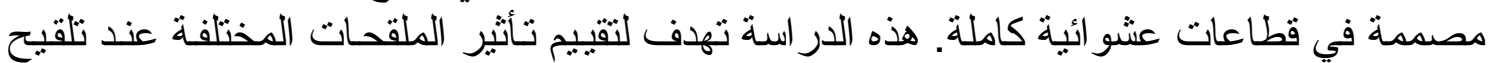

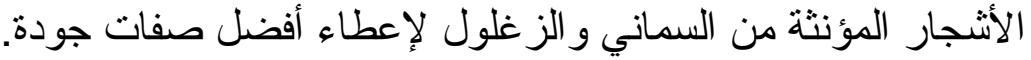
اللقاح من كل ملقح أُعطى رقم كودي هو : (IV, III, II, I) و استخدم لتلقيح إنـاث البلح

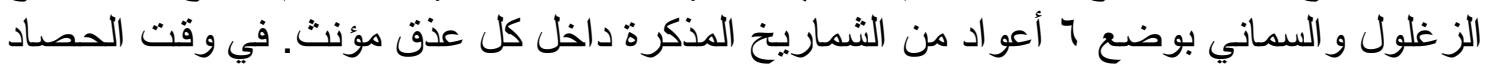

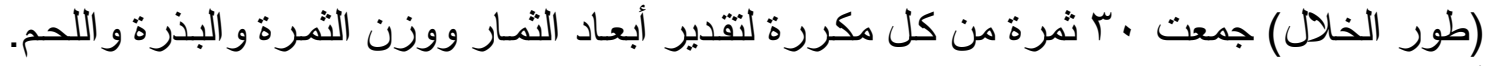

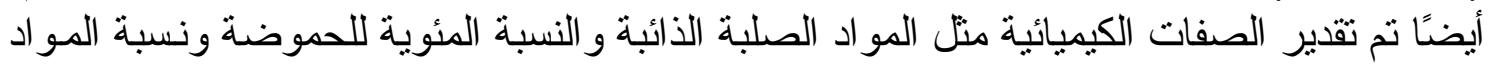

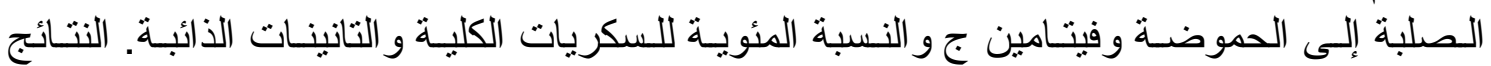

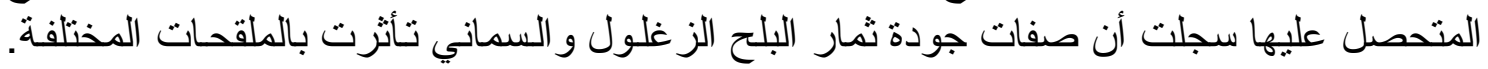

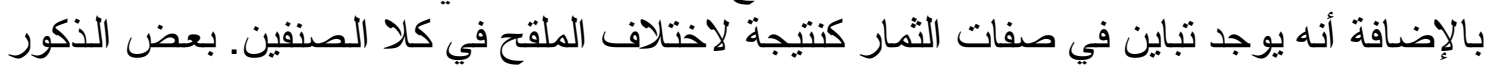

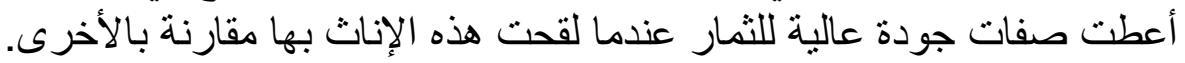

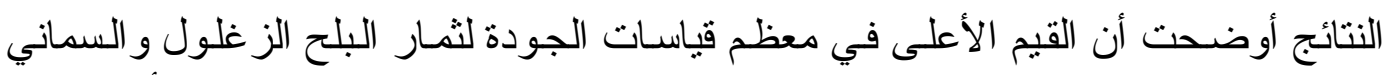
حصل عليها عندما تم التلقيح بالملقح رقم II. لذلك نحن نوصسي بإكثار الملقح رقم II دأي طريقة متاحة. 